\title{
Radioguided occult lesion localization for minimally- invasive parathyroidectomy without quick PTH monitoring and frozen section: impact of the learning
} curve

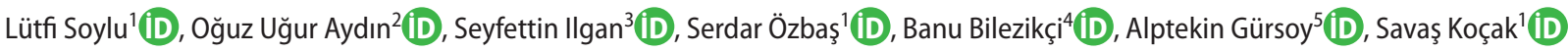

\author{
${ }^{1}$ Department of Endocrine Surgery, Ankara Guven Hospital, Ankara, Turkey \\ ${ }^{2}$ Department of Endocrine Surgery, Ankara Medicana International Hospital, Ankara, Turkey \\ ${ }^{3}$ Department of Nuclear Medicine, Ankara Guven Hospital, Ankara, Turkey \\ ${ }^{4}$ Department of Pathology, Ankara Guven Hospital, Ankara, Turkey \\ ${ }^{5}$ Department of Endocrinology, Ankara Guven Hospital, Ankara, Turkey
}

\section{ABSTRACT}

Objective: Minimally-invasive parathyroidectomy (MIP) is a surgical procedure that reduces the duration of operation, hospital costs, and hypocalcemia, and shortens the length of hospital stay. This study addressed the important procedural details of the radioguided occult lesion localization (ROLL)-MIP technique and evaluated the consequences of the learning curve from a series of patients.

Material and Methods: A total of 80 patients who underwent ROLL-MIP for a single parathyroid adenoma were included into this retrospective study. In order to analyze the effect of the learning curve, these subjects were then divided into 2 groups per time period and the operative times were compared. Group A consisted of 22 previously reported patients who served as the control group. Group B consisted of 58 consecutive patients.

Results: Serum calcium and parathyroid hormone (PTH) levels were normalized in all of the patients within 2 days and remained normal during the followup period ( $31 \pm 18.5$ months). None of the patients who underwent ROLL-guided parathyroidectomy suffered temporary or permanent recurrent laryngeal nerve injuries. Mean operation time (time from incision to excision of the adenoma) was $23 \pm 6$ min in Group A and $18 \pm 7$ min in Group B. Mean operative times were significantly shorter in group $B$.

Conclusion: The success of MIP administered with the ROLL technique in a single adenomatous patient was quite high. This method seems especially valuable in patients with atypically located or small adenomas.

Keywords: Parathyroid adenoma, minimally-invasive parathyroidectomy, radioguided occult lesion localization

Cite this article as: Soylu L, Aydın OU, Ilgan S, Özbaş S, Bilezikçi B, Gürsoy A, et al. Radioguided occult lesion localization for minimally-invasive parathyroidectomy without quick PTH monitoring and frozen section: impact of the learning curve. Turk J Surg 2020; 36 (3): 297-302.

\section{Corresponding Author}

Lütfi Soylu

E-mail: lutfisoylu@hotmail.com

Received: 21.03.2019

Accepted: 24.04 .2020

Available Online Date: 28.09 .2020

๑ Copyright 2020 by Turkish Surgical Society Available online at www.turkjsurg.com

DOI: $10.47717 /$ turkjsurg.2020.4470

\section{INTRODUCTION}

Primary hyperparathyroidism (pHPT) is a generalized disorder of calcium, phosphate, and bone metabolism caused by an increased secretion of the parathyroid hormone, with a prevalence of 1-3\% in western countries. The most common clinical presentation of pHPT is asymptomatic hypercalcemia (1-4). It is explained by a single parathyroid adenoma in most of the cases (80\%-85\%), followed by hyperplasia, double adenomas, and parathyroid carcinoma.

Surgery continues to remain the mainstay of treatment for patients with symptomatic PHPT (nephrolithiasis, symptomatic hypercalcemia). Indications for surgery during the monitoring of asymptomatic patients include an increase in serum calcium $1 \mathrm{mg} / \mathrm{dL}$ above the upper normal limit, a decreased glomerular filtration rate $(<60 \mathrm{~mL} / \mathrm{min})$, a reduction in bone density and/or the occurrence of fragility fracture, the occurrence of nephrolithiasis or nephrocalcinosis on the imaging study, and an age of $<50$ years (5).

The unilateral focused surgical approach, known as minimally-invasive parathyroidectomy (MIP), is becoming more widespread, because it results in reduced operative time, lower hospital costs, a shorter hospital stay, and fewer events of transient hypocalcemia with cure rates equal to that of formal bilateral neck exploration. 
Radioguided occult lesion localization (ROLL) is a new localization technique originally described for nonpalpable breast lesions (6). Recently, it has been reported that the use of ROLL for MIP in patients with PHPT due to a single parathyroid adenoma in the neck is technically safe and effective (7). It has also been shown that the ROLL technique does not impair the postoperative histopathological examination of the parathyroid glands.

Implementation of new procedures, including the ROLL-MIP, must be done in a responsible way to ensure that the procedures are performed correctly. This study addressed the important procedural details of the ROLL-MIP technique and evaluated the consequences of the learning curve from a series of patients.

\section{MATERIAL and METHODS}

A total of 80 patients who underwent ROLL-MIP for a single parathyroid adenoma were studied in this retrospective study. The study was conducted in accordance with the ethical standards set by the Declaration of Helsinki. Informed consent was obtained from all individual participants included into the study.

All diagnostic imaging studies and US-guided interventions were conducted by the same team member and all patients were operated on by the same surgical team headed by one of our senior endocrine surgeons.

All patients underwent a localization study consisting of dual-phase MIBI scintigraphy and high-resolution US. The parathyroid adenoma was localized preoperatively by scintigraphy and/ or US. Diagnosis was confirmed by measuring the PTH in the needle aspirate of the suspicious lesions if scintigraphy and US were inconclusive or discordant. Since the recognition of an adenoma on a US is a prerequisite for ROLL, patients were excluded from the study when their cause of PHPT was neither correlated nor localized sonographically. Exclusion criteria were suspicion of multiple gland disease, multiple endocrine neoplasm syndrome, and thyroid disease requiring thyroidectomy. Surgical success was defined as the excision of the preoperatively identified lesions and normalization of the PTH and serum calcium levels.

\section{Statistical Analysis}

Analysis of the data was done using the IBM SPSS 25.0 statistical package program. Descriptive statistical methods (frequency, percentage, median, min-max) were used when the study data were evaluated. Normal distribution of the data was assessed using the Kolmogorov-Smirnow and Shapiro-Wilk tests, and the data were not normal. In the study, the Mann-Whitney $U$ test was used for comparisons between the groups. Likelihood (P) values smaller than $\boldsymbol{v}=0.05$ were significant and there was a difference between the groups, with large values being insignificant and no differences between the groups.

\section{Patients}

The study group consisted of all of the surgical candidates presenting at the Department of Endocrine Surgery of Güven Hospital with pHPT due to a single adenoma between September 2011 and November 2017. In order to analyze the effect of the learning curve, these subjects were then divided into 2 groups per time period, and the operative times were compared. Group A consisted of the first 22 previously reported patients, who served as the control group. Group B consisted of 58 consecutive patients enrolled between January 2014 and November 2017.

Group A included 3 males and 19 females, with an average age of $56 \pm 14$ years (35-85 years) at the time of primary diagnosis. Four out of the 22 patients had previously undergone thyroid/ parathyroid surgery. Group B included 19 males and 39 females, with an average age of $50 \pm 14$ years (22-87 years) at the time of primary diagnosis. Of the patients in both groups, 10 had previously undergone thyroid/parathyroid surgery (4 in Group A, 6 in Group B). Demographic data, preoperative and postoperative serum calcium and PTH levels, localization of the adenoma, and operative time (time from incision to excision of the adenoma) were available for all patients (Table I). Final diagnosis was confirmed histopathologically.

\section{Imaging studies and ROLL technique}

We have previously described our imaging techniques and interventions for ROLL MIP. Briefly, the diagnosed single parathyroid adenomas were injected with 3.7-5.55 MBq (0.1-0.15 mCi) of Tc-99m labeled macro-aggregated albumin (MAA) on the morning of surgery, using a tuberculin syringe equipped with a $22-\mathrm{G}$ standard needle under US guidance. The total injected volume was $0.1-0.15 \mathrm{~mL}$, depending on the size of the adenoma.

\section{Surgery}

All patients were operated on under general anesthesia. Surgery was focused on the preoperatively located and injected index gland. Parathyroid adenomas were searched for and localized over the skin with a gamma probe equipped with an 11-mm angled probe (Europrobe 3; EuroMedical Instrument, Paris, France) to decide the best incision level (Figure 1). Midline incisions were made in a skin fold at an appropriate level according to gamma probe measurements. The incisions were slightly weighted toward the expected side of the adenoma. Excised lesions were counted ex-vivo with the gamma probe to make sure that the preoperatively detected and injected lesion had been found (Figure 2,3). Frozen sections and intraoperative quick PTH monitoring were not routinely used. Time from incision to excision of the adenoma (operative time) was recorded. Postoperative follow-up consisted of the evaluation of serum calcium and PTH levels sampled at 6-8 h after surgery. The patients were discharged on calcium and vitamin D supplementation for 2 weeks, with a control visit after 1 week. 
Table 1. Group demographics and comparisons

\begin{tabular}{|c|c|c|c|}
\hline & Group A $(n=22)$ & Group B $(n=58)$ & $\mathrm{p}$ \\
\hline \multicolumn{4}{|l|}{ Sex } \\
\hline Female & $19(86.4 \%)$ & $37(63.8 \%)$ & \multirow[t]{2}{*}{$0.090^{a}$} \\
\hline Male & $3(13.6 \%)$ & $21(36.2 \%)$ & \\
\hline Age $^{*}$ (years) & $57(35-85)$ & $46(22-87)$ & $0.091^{b}$ \\
\hline Operative time* $(\mathrm{min})$ & $23(13-35)$ & $16(8-45)$ & $0.000^{b}$ \\
\hline \multicolumn{4}{|l|}{ Adenoma Location } \\
\hline $\mathrm{LI}$ & $7(31.8 \%)$ & $25(43.1 \%)$ & \multirow{4}{*}{$0.000^{\mathrm{a}}$} \\
\hline LS & $6(27.3 \%)$ & $5(8.6 \%)$ & \\
\hline $\mathrm{Rl}$ & $2(9.1 \%)$ & $25(43.1 \%)$ & \\
\hline RS & $7(31.8 \%)$ & $3(5.2 \%)$ & \\
\hline Size on US* $(m m \times m m)$ & $73(21-248)$ & $150(21-1320)$ & $0.000^{b}$ \\
\hline \multicolumn{4}{|l|}{ Previous cervical exploration } \\
\hline- & $18(81.8 \%)$ & $52(89.7 \%)$ & \multirow{5}{*}{--} \\
\hline $\mathrm{TT}$ & $2(9.1 \%)$ & $5(8.6 \%)$ & \\
\hline BST & -- & $1(1.7 \%)$ & \\
\hline $\mathrm{BST}+\mathrm{CTX}$ & $1(4.5 \%)$ & -- & \\
\hline UE & $1(4.5 \%)$ & -- & \\
\hline
\end{tabular}

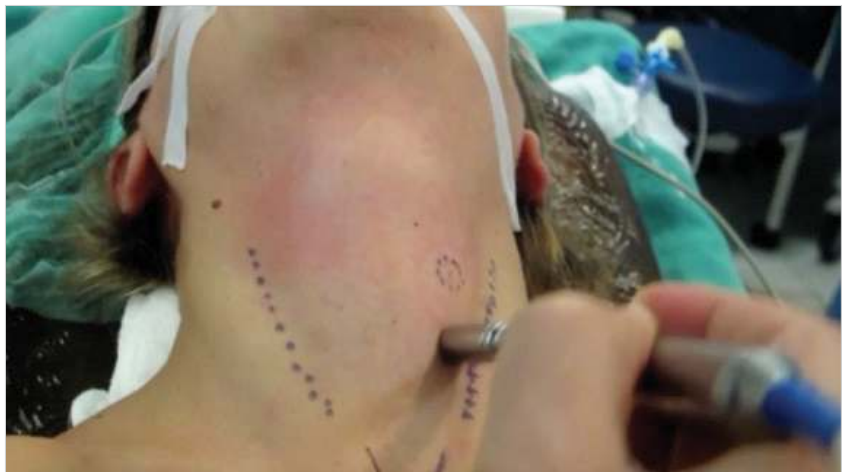

Figure 1. Lack of background activity makes the detection of the injected adenomas with gamma probe over the skin easier during the ROLL-MIP technique. This facilitates the selection of the best incision level before surgery.

\section{RESULTS}

Localization of the adenoma was determined based on the PTH levels in the needle washout in 26 patients, by concordant US and scintigraphy results in 41 patients, and by only US results in 13 patients. The size of the successfully biopsied or injected lesions ranged from $7 \times 3 \mathrm{~mm}$ to $40 \times 33 \mathrm{~mm}$ in diameter. Parathyroid adenomas were found in inferior parathyroid locations in 59 (73.75\%) patients (32 left inferior, 27 right inferior) and in superior parathyroid locations in 21 (26.25\%) patients (11 left superior, 10 right superior). US-guided interventions were made without local anesthesia and were well-tolerated without complications in 78 patients. In the remaining 2 patients, who had a phobia of needle procedures, the injections were made after general anesthesia in the operating room.

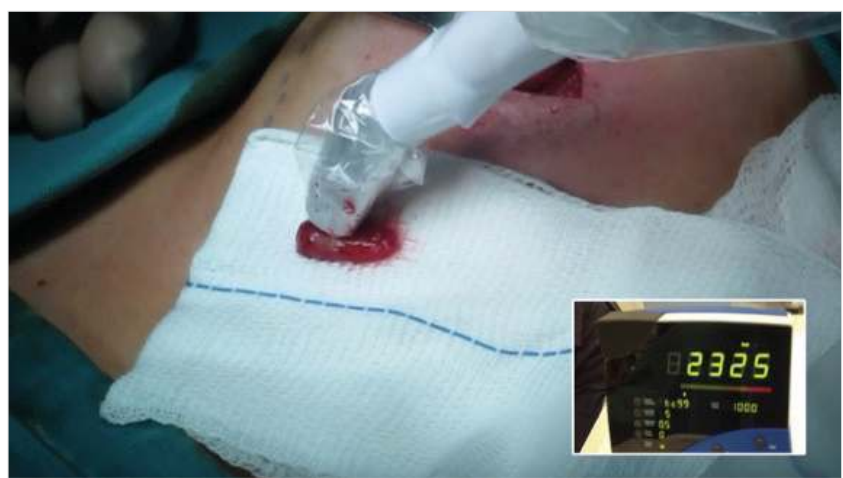

Figure 2. Ex-vivo counting of the excised parathyroid adenoma after removal. The count ratio from the excised adenoma to the lesion bed is always high enough to determine an effective removal of the lesions. Reflux of the injected radiopharmaceutical may cause recognizable residual activity in the lesion bed, especially in small adenomas. This should not alert the surgeon to incomplete surgical excision if completeness of the adenoma is visually confirmed.

\section{Radioguided Surgery}

All of the injected lesions were successfully located over the skin with the gamma probe. Despite previous cervical explorations in 10 patients, the gamma probe safely guided the surgeon to the preoperatively injected lesions. Mean operation time (time from incision to excision of the adenoma) was $23 \pm 7 \mathrm{~min}$ in Group A and $18 \pm 7$ min in Group B. Mean operative times were significantly shorter in group B.

Serum calcium and PTH levels normalized in all of the patients within 2 days and remained normal during the follow-up peri- 


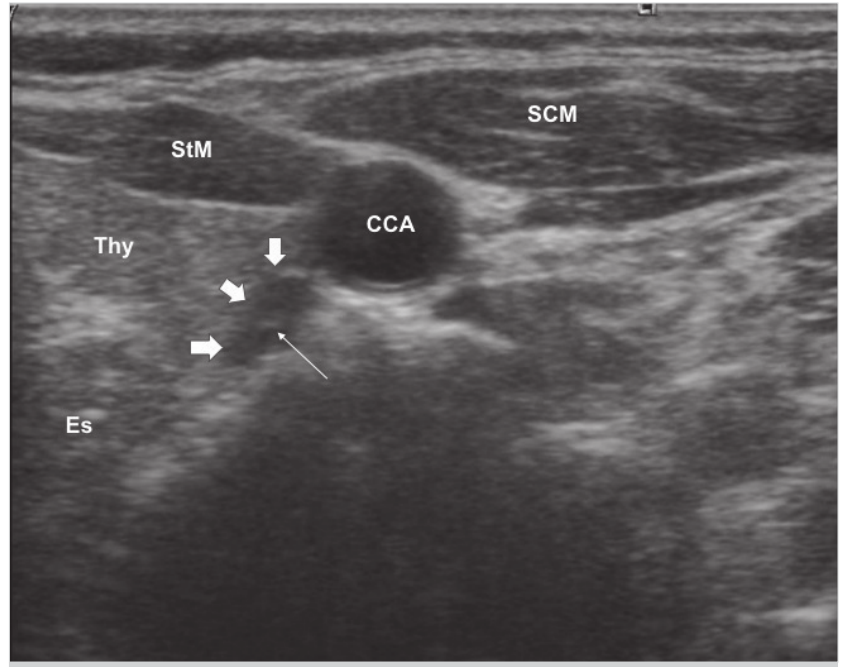

Figure 3. The axial slice of the left thyroid lobe shows a markedly hypoechoic solid lesion, which is typical with extra thyroidal parathyroid adenoma (thick arrows). Thin arrow shows the hyperechoic needle tip at the center of the lesion during injection.

CCA: Left common carotid artery, StM: Strap muscles, SCM: Sternocleidomastoid muscle, Thy: Left thyroid lobe, Es: Esophagus.

od (31 \pm 18.5 months). None of the patients who underwent ROLL-guided parathyroidectomy suffered temporary or permanent recurrent laryngeal nerve injuries. No wound infection, seroma formation, or hematomas occurred in our patients.

\section{DISCUSSION}

pHPT is a complex endocrinopathy involving calcium metabolism and a potent hormone made by the parathyroid glands. Diagnosis is confirmed by inappropriately elevated parathyroid hormone levels accompanied by high-normal or elevated serum calcium. Although classic presentation of pHPT involves the presence of renal stones, bone loss, and gastrointestinal complaints, the screening of serum calcium levels during routine medical examinations has changed the clinical spectrum to include patients with minimally objective symptoms who are referred to as "asymptomatic".

Over the past decade, there has been a shift towards MIP; a focused operation whereby only 1 parathyroid is removed. Compared to the conventional neck exploration, in which all 4 glands are investigated intra-operatively, MIP is associated with a shorter operating time, lower complication rates, smaller incision size, shorter hospital stay, and greater patient satisfaction (8-11).

Imaging is critical in order to enable successful MIP. Aside from its ability to localize the pathological gland(s), accurate imaging provides valuable anatomical information for the surgeon.

Preoperative localization studies have been regarded as necessary but their use is still controversial (12). Some authors suggest that these studies may reduce surgical time, technical failures, complication rates (13) by improving PHPT operation by MIP (14), and radioguided surgery $(15,16)$. Several imaging techniques, such as neck ultrasound (US) $(17,18)$, computerized tomography (CT) (19), and dual-phase Tc-99m MIBI scan with single-photon emission CT (SPECT)/CT are currently available (20) although neck US and MIBI scans are generally used as the first tools in the diagnostic approach of pHPT (21).

ROLL-MIP seems to have several advantages over standard radioguided MIP with an intravenous injection of TC-99m MIBI: 1) It is independent from the uptake potential of the diseased parathyroid glands and could be used in patients with negative MIBI scintigraphy, 2) It requires very small activity compared with the systemic injection of Tc-99m MIBI (0.1-0.15 mCi vs. 15$20 \mathrm{mCi}), 3$ ) The ROLL technique does not cause background activity and potentially gives the best lesion-to-background count ratios, 4) Contrary to the intravenous injection method, the lack of background activity makes the detection of injected adenomas with a gamma probe over the skin easier and facilitates the selection of the incision level as well, and 5) the technique warrants the excision of the preoperatively located adenoma since direct inoculation of Tc-99m labeled particles does not cause false-positive results like an intravenous injection of Tc$99 \mathrm{~m} \mathrm{MIBI}$.

In our series, all of the preoperatively depicted parathyroid adenomas were found in a timely manner ( $23 \pm 7 \mathrm{~min}$ in Group A, $18 \pm 7$ min in Group B) for the entire study group, including inpatients that had undergone previous neck explorations. In this study, we observed the effect of the learning curve over the duration of the operation, which generally showed a decrease in the duration of the operation as experience increased.

In general, MIP shortens operative and anesthesia time (22-24). In the literature, mean operation time of MIP ranges from 15 to 56 min $(25,26)$. It also shortens hospitalization time (19). In this study, duration of the surgery was short $19.4 \pm 7.2$ (8-45 min) in the whole group and the patients were not hospitalized for longer than 1 day.

None of the patients had a permanent rise in their PTH and serum calcium levels or required a reoperation due to insufficient resection. In our study, we reached a 100\% success rate without requiring additional tests like intraoperative quick PTH monitoring and frozen section.

In summary, the success of the ROLL-MIP technique without rapid PTH measurement and frozen section was quite high in patients with single adenoma. Repeated application of the ROLL-MIP technique resulted in a significant decrease in operative time, as expected. The technique seems to be particularly valuable in patients with atypically located or small adenomas. 
Ethics Committee Approval: Ethics committee approval was received for this study from the Local Ethics Committee of Ankara Guven Hospital (18.03.2020)

Peer-review: Externally peer-reviewed.

Author Contributions: Concept - L.S., O.U.A., S.I., Design - L.S., S.I., S.Ö., O.U.A., Supervision - L.S., B.B., S.Ö., Resource - L.S., S.I., S.Ö., Data Collection and/or Processing - L.S., S.I., B.B., S.K., A.G.; Analysis and Interpretation - S.I., S.K., A.G.; Literature Review - S.K., B.B., A.G.; Writing Manuscript - L.S., S.I, S.Ö.; Critical Reviews - S.I., S.Ö., A.G., S.K., O.U.A.

Conflict of Interest: The authors have no conflicts of interest to declare.

Financial Disclosure: The authors declared that this study has received no financial support.

\section{REFERENCES}

1. Lubitz CC, Stephen AE, Hodin RA, Pandharipande P. Preoperative localization strategies for primary hyperparathyroidism: an economic analysis. Ann Surg Oncol 2012; 19: 4202-9. [CrossRef]

2. Philippon M, Guerin C, Taieb D, Vaillant J, Morange I, Brue T, et al. Bilateral neck exploration in patients with primary hyperparathyroidism and discordant imaging results: a single-center study. Eur J Endocrinol 2014; 170: 719-25. [CrossRef]

3. Marcocci C, Cetani F. Clinical practice: primary hyperparathyroidism. N Engl J Med 2011; 365: 2389-97. [CrossRef]

4. Kelly CWP, Eng CY, Quraishi MS. Open mini-incision parathyroidectomy for solitary parathyroid adenoma. Eur Arch Otorhinolaryngol 2014; 271:555-60. [CrossRef]

5. Bilezikian JP, Brandi ML, Eastell R, Silverberg SJ, Udelsman R, MarcocCi $C$, et al. Guidelines for the management of asymptomatic primary hyperparathyroidism: summary statement from the Fourth International Workshop. J Clin Endocrinol Metab 2014; 99: 3561-9. [CrossRef]

6. Nadeem R, Chagla LS, Harris O, Desmond S, Thind R, Titterrell C, et al. Occult breast lesions: a comparison between radioguided occult lesion localisation (ROLL) vs. wire guided lumpectomy (WGL). Breast 2005; 14: 283-9. [CrossRef]

7. Ilgan S, Ozbas S, Bilezikci B, Sengezer T, Aydin OU, Gursoy A, et al. Radioguided occult lesion localization for minimally invasive parathyroidectomy: technical consideration and feasibility. Nucl Med Commun 2014; 35: 1167-74. [CrossRef]

8. Sackett WR, Barraclough B, Reeve TS, Delbridge LW. Worldwide trends in the surgical treatment of primary hyperparathyroidism in the era of minimally invasive parathyroidectomy. Arch Surg 2002; 137: 1055-9. [CrossRef]

9. Irvin GL, Carneiro DM, Solorzano CC. Progress in the operative management of sporadic primary hyperparathyroidism over 34 years. Ann Surg 2004; 239: 704-8. [CrossRef]

10. Grant CS, Thompson G, Farley D, van Heerden J. Primary hyperparathyroidism surgical management since the introduction of minimally invasive parathyroidectomy: Mayo Clinic experience. Arch Surg 2005; 140: 472-9. [CrossRef]

11. McGill J, Sturgeon C, Kaplan SP, Chiu B, Kaplan EL, Angelos P. How does the operative strategy for primary hyperparathyroidism impact the findings and cure rate? A comparison of 800 parathyroidectomies. J Am Coll Surg 2008; 207: 246-9. [CrossRef]
12. Udelsman R. Six hundred fifty-six consecutive explorations for primary hyperparathyroidism. Ann Surg 2002; 235: 665-70. [CrossRef]

13. Siperstein A, Berber E, Mackey R, Alghoul M, Wagner K, Milas M. Prospective evaluation of sestamibi scan, ultrasonography, and rapid PTH to predict the success of limited exploration for sporadic primary hyperparathyroidism. Surgery 2004; 136: 872-80. [CrossRef]

14. BergenfelzA, Lindblom P, Tibblin S, WesterdahIJ. Unilateral versus bilateral neck exploration for primary hyperparathyroidism: a prospective randomized controlled trial. Ann Surg 2002; 236: 543-51. [CrossRef]

15. Henry JF, lacobone M, Mirallie E, Deveze A, Pili S. Indications and results of video-assisted parathyroidectomy by a lateral approach in patients with primary hyperparathyroidism. Surgery 2001; 130: 9991004. [CrossRef]

16. Abraham D, Sharma PK, Bentz J, Gault PM, Neumayer L, McClain DA. Utility of ultrasound-guided fine-needle aspiration of parathyroid adenomas for localization before minimally invasive parathyroidectomy. Endocr Pract 2007; 13: 333-7. [CrossRef]

17. Mitchell BK, Merrell RC, Kinder BK. Localization studies in patients with hyperparathyroidism. Surg Clin North Am 1995; 75: 483-98. [CrossRef]

18. Gofrit ON, Lebensart PD, Pikarsky A, Lackstein D, Gross DJ, Shiloni E. High-resolution ultrasonography: highly sensitive, specific technique for preoperative localization of parathyroid adenoma in the absence of multinodular thyroid disease. World J Surg 1997; 21: 287-90. [CrossRef]

19. Tziakouri C, Eracleous E, Skannavis S, Pierides A, Symeonides P, Gourtsoyiannis $N$. Value of ultrasonography, CT and MR imaging in the diagnosis of primary hyperparathyroidism. Acta Radiol 1996; 37: 720-6. [CrossRef]

20. Johnston LB, Carroll MJ, Britton KE, Lowe DG, Shand W, Besser GM, et al. The accuracy of parathyroid gland localization in primary hyperparathyroidism using sestamibi radionuclide imaging. J Clin Endocrinol Metab 1996; 81: 346-52. [CrossRef]

21. Haber RS, Kim CK, Inabnet WB. Ultrasonography for preoperative localization of enlarged parathyroid glands in primary hyperparathyroidism: comparison with (99m)technetium sestamibi scintigraphy. Clin Endocrinol (Oxf) 2002; 57: 241-9. [CrossRef]

22. Gilat H, Cohen M, Feinmesser R, Benzion J, Shvero J, Segal K, et al. Minimally invasive procedure for resection of a parathyroid adenoma: the role of preoperative high resolution ultrasonography. J Clin Ultrasound 2005; 33: 283-7. [CrossRef]

23. Smit PC, Borel Rinkes IH, van Dalen A, van Vroonhoven TJ. Direct, minimally invasive adenomectomy for primary hyperparathyroidism: An alternative to conventional neck exploration? Ann Surg 2000; 231: 559-65. [CrossRef]

24. Ulanovski D, Feinmesser R, Cohen M, Sulkes J, Dudkiewicz M, Shpitzer T. Preoperative evaluation of patients with parathyroid adenoma: role of high-resolution ultrasonography. Head Neck 2002; 24: 1-5. [CrossRef]

25. Teksoz S, Bukey Y, Ozcan M, Arikan AE, Erbabacan SE, Ozyegin A. Minimal invasive parathyroidectomy with local anesthesia for welllocalized primary hyperparathyroidism: "Cerrahpasa experience". Updates Surg 2013; 65:217-23. [CrossRef]

26. Cohen MS, Finkelstein SE, Brunt LM, Haberfeld E, Kangrga I, Moley JF, et al. Outpatient minimally invasive parathyroidectomy using local/ regional anesthesia: a safe and effective operative approach for selected patients. Surgery 2005; 138:681-7. [CrossRef] 


\section{ORIJINAL ÇALIŞMA-ÖZET}

Turk J Surg 2020; 36 (3): 297-302

\section{Hızlı PTH ölçümü ve frozen inceleme olmadan occult lezyonlarda radyolojik kılavuzlu minimal invaziv paratiroidektomi: öğrenme eğrisinin etkisi}

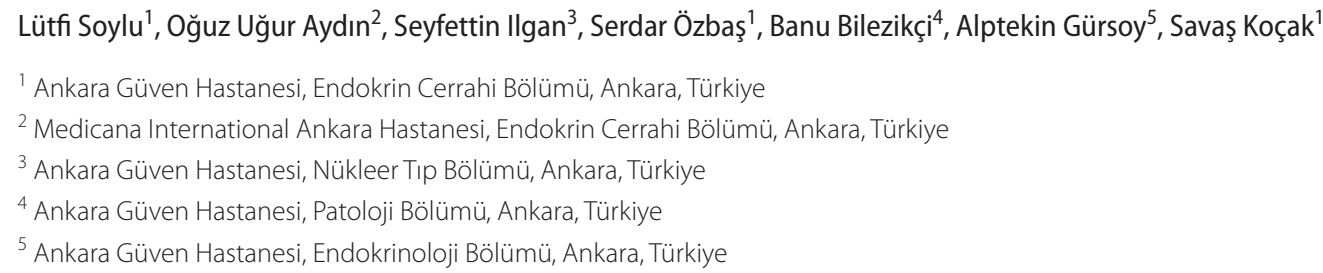

\section{ÖZET}

Giriş ve Amaç: Minimal invaziv paratiroidektomi (MIP); operasyon süresini, hastane maliyetlerini ve hipokalsemiyi azaltan ve hastanede kalış süresini kısaltan cerrahi bir işlemdir. Bu çalışma, radyoaktif madde ile küçük lezyon lokalizasyonunun (ROLL)-MIP tekniğinin önemli prosedürel detaylarını ele almakta ve bir dizi hastadan gelen öğrenme eğrisinin sonuçlarını değerlendirmektedir.

Gereç ve Yöntem: Bu retrospektif çalışmada tek paratiroid adenomu için ROLL-MIP uygulanan toplam 80 hasta incelendi. Öğrenme eğrisinin etkisini analiz etmek için hastalar operasyon zamanlarına göre 2 gruba ayrıldı ve operasyon zamanları karşılaştıııldı. Grup A, daha önce kontrol grubu olarak görev yapan 22 hastadan oluşuyordu. B grubu ardışık 58 hastadan oluşuyordu.

Bulgular: Serum kalsiyum ve paratiroid hormonu (PTH) düzeyleri tüm hastalarda 2 gün içerisinde normalize edildi ve takiplerinde (31 \pm 18.5 ay) normal kaldı. ROLL eşliğinde paratiroidektomi yapılan hiçbir hastada geçici veya kalıcı rekürren laringeal sinir yaralanması olmadı. Ortalama ameliyat süresi (insizyondan adenomun eksizyonuna kadar geçen süre) Grup A'da $23 \pm 6$ dakika ve Grup B'de $18 \pm 7$ dakika idi. Ortalama ameliyat süresi grup B'de anlamlı olarak kısaydı.

Sonuç: Tek adenomalı hastalarda ROLL tekniği ile uygulanan MIP başarısı oldukça yüksekti. Bu yöntem özellikle atipik yerleşimli veya küçük adenomlu hastalarda değerli gibi görünmektedir.

Anahtar Kelimeler: Paratiroid adenomu, minimal invaziv paratiroidektomi, radyoaktif madde yardımlı occult lezyon

Doi: $10.47717 /$ turkjsurg.2020.4470 